\title{
Pengembangan multimedia pembelajaran untuk meningkatkan hasil belajar kognitif materi sistem respirasi
}

\author{
Din Hadi Shofyan, Siti Zubaidah*, Amy Tenzer \\ Universitas Negeri Malang, Jl. Semarang No. 5 Malang, Jawa Timur, Indonesia \\ *Penulis korespondensi, Surel: siti.zubaidah.fmipa@um.ac.id
}

Paper received: 02-01-2021; revised: 15-01-2021; accepted: 30-01-2021

\begin{abstract}
Observations in MAN Malang II Batu and giving questionnaires to a number of students shows that students still have difficulty understanding abstract concepts on the material of the respiratory system. It can also be seen from the thoroughness of classical study that has not been achieved. The use of instructional media is still minimal and less attractive to students, believed to be a major factor to the achievement of mastery learning klasial. To that end, the development of multimedia learning based on flash needs to be done on the grounds can create a variety of interesting and illustrative media. With the learning multimedia is expected to facilitate students in understanding the abstract concepts of matter respiratory system and learning becomes fun.
\end{abstract}

Keywords: media; learning multimedia

\begin{abstract}
Abstrak
Penelitian dan pengembangan ini bertujuan untuk mengembangkan multimedia pembelajaran berbasis flash untuk meningkatkan hasil belajar kognitif siswa materi sistem respirasi manusia serta menguji kelayakan, kepraktisan dan keefektifannya. Model pengembangan menggunakan Four-D model yang dibatasi sampai tahap III (pengembangan). Hasil uji kelayakan, kepraktisan dan keefektifan menunjukkan bahwa multimedia yang dikembangkan memiliki kriteria sangat layak, sangat praktis, serta efektif. Dapat disimpulkan bahwa multimedia pembelajaran berbasis flash memiliki kriteria sangat layak, sangat praktis dan efektif sehingga mampu meningkatkan hasil belajar kognitif siswa.
\end{abstract}

Kata kunci: media; multimedia pembelajaran.

\section{Pendahuluan}

Proses pembelajaran merupakan suatu proses komunikasi, yaitu penyampaian pesan dari sumber pesan melalui media tertentu ke penerima pesan (Suherman, 2009). Komponenkomponen dalam proses pembelajaran di kelas adalah materi pelajaran sebagai pesan, guru dan peserta didik sebagai sumber pesan (lebih cenderung ke guru), semua saluran media pendidikan sebagai media pembelajaran, peserta didik atau juga guru sebagai penerima pesan (lebih cenderung ke peserta didik).

Banyak permasalahan yang timbul dalam proses pembelajaran biologi di kelas. Berdasarkan studi dokumen rapor sisipan menunjukkan bahwa tingat ketuntasan belajar klasikal belum tercapai pada materi sistem respirasi. Berdasarkan observasi juga diketahui bahwa media yang digunakan pada proses pembelajaran masih minim dan kurang diminati oleh peserta didik.

Sayekti, dkk (2011) menunjukkan penggunaan multimedia pembelajaran sebagai media pembelajaran untuk meningkatkan pemahaman peserta didik terhadap konsep yang 
bersifat abstrak khususnya materi yang memiliki objek kajian yang padat dan membutuhkan media yang beragam untuk menyampaikan pesan yang terkandung di dalam materi tersebut. Konsep yang tidak dapat diamati secara langsung, dapat diilustrasikan menggunakan gambar, animasi, atau tayangan video untuk memberikan persamaan persepsi terhadap peserta didik. Selain itu, fasilitas navigasi yang tersedia, memungkinkan peserta didik untuk terlibat langsung dalam proses pembelajaran.

Multimedia pembelajaran merupakan salah satu media pembelajaran perangkat lunak yang dapat dikembangkan menggunakan aplikasi flash. Flash adalah salah satu perangkat lunak komputer yang digunakan untuk membuat gambar, grafik, animasi, game, menyisipkan suara, video dan teks (Enterprise, 2007). Selain itu flash juga dilengkapi action scrypt.

Penelitian yang dilakukan oleh Zalikha (2008) menunjukkan bahwa penggunaan multimedia pembelajaran berbasis flash pada pembelajaran biologi materi sistem reproduksi manusia dapat meningkatkan hasil belajar kognitif siswa. Berdasarkan hasil penelitian dari Bagus (2012), penggunaan multimedia pembelajaran berbasis flash pada proses pembelajaran ekonomi, dapat meningkatkan hasil belajar siswa.

Berdasarkan latar belakang tersebut, pengembangan multimedia pembelajaran berbasis flash pada materi sistem respirasi perlu untuk dilakukan. Multimedia yang dikembangkan diharapkan menarik dan dapat memudahkan siswa untuk memahami konsep abstrak pada materi sistem respirasi.

\section{Metode}

Model pengembangan yang digunakan dalam penelitian dan pengembangan ini mengadaptasi tahapan-tahapan dari Four-D model yang dikembangkan oleh Thiagarajan, dkk. (1974) tetapi hanya dibatasi sampai tahap III karena keterbatasan waktu, tenaga dan biaya peneliti. Langkah pertama adalah mengembangkan multimedia pembelajaran berbasis flash materi sistem respirasi manusia. Setelah produk selesai dikembangkan, langkah selanjutnya adalah menguji kualitas multimedia dari segi media, materi dan strategi pembelajaran oleh validator media, validator materi dan praktisi lapangan. Multimedia akan direvisi berdasarkan saran dan masukan dari ketiga validator. Multimedia akan terus direvisi sampai benar-benar dinyatakan layak untuk diujicobakan ke lapangan. Setelah multimedia dinyatakan layak, selanjutnya diujicobakan ke lapangan. Uji coba lapangan untuk mengetahui kualitas multimedia dari aspek kepraktisan, dan keefektifannya sekaligus menjadi produk akhir dari penelitian dan pengembangan ini.

Instrumen penelitian yang digunakan antara lain: (1) lembar validasi ahli media untuk mengukur kelayakan media dari aspek media; (2) lembar validasi ahli materi untuk mengukur kelayakan media dari aspek materi; (3) lembar validasi praktisi lapangan untuk mengukur kelayakan media dari aspek strategi pembelajaran; (4) angket kepraktisan multimedia untuk mengukur kepraktisan multimedia dari segi kemenarikan, kemudahan untuk dioperasikan dan kemudahan materi untuk dipelajari; (5) soal tes ulangan harian materi sistem respirasi manusia untuk mengukur keefektifan multimedia. Data yang diperoleh dari lembar validasi dan angket kepraktisan kemudian dianalisis dan ditafsirkan berdasarkan kualifikasi penilaian dengan kriteria sangat layak/sangat praktis, layak/praktis, cukup layak/cukup praktis, tidak layak/tidak praktis. Data yang diperoleh dari sooal ulangan harian kemudian dianalisis untuk mengetahui tingkat 
ketuntasan belajar klasikal. Apabila tingkat ketuntasan belajar klasikal memenuhi standard minimal $\geq 85 \%$ maka multimedia yang telah dikembangkan memiliki kriteria efektif.

\section{Hasil dan Pembahasan}

\subsection{Uji Kelayakan Multimedia}

Skor oleh validator media, validator materi dan praktisi lapangan menunjukkan bahwa multimedia yang dikembangkan memiliki kriteria sangat layak dari aspek media, materi dan strategi pembelajaran. Skor oleh validator media, validator materi dan praktisi lapangan dapat dilihat pada Tabel 1, 2 dan 3.

Tabel 1. Rekapitulasi Data Hasil Validasi oleh Ahli Media

\begin{tabular}{|c|c|c|c|c|c|}
\hline No & Komponen yang Dinilai & $\mathrm{X}$ & $\mathrm{Xi}$ & $\begin{array}{l}\text { Persenta } \\
\text { se \% }\end{array}$ & Kriteria \\
\hline 1 & Reliable (handal) & 4,00 & 4,00 & 100,00 & Sangat Layak \\
\hline 2 & $\begin{array}{l}\text { Maintainable (dapat } \\
\text { dipelihara/dikelola dengan } \\
\text { mudah) }\end{array}$ & 4,00 & 4,00 & 100,00 & Sangat layak \\
\hline 3 & $\begin{array}{l}\text { Usabilitas (mudah digunakan } \\
\text { dan sederhana dalam } \\
\text { pengoperasian) }\end{array}$ & 3,00 & 4,00 & 75,00 & Cukup Layak \\
\hline 4 & $\begin{array}{l}\text { Ketepatan jenis aplikasi untuk } \\
\text { pengembangan }\end{array}$ & 4,00 & 4,00 & 100,00 & Sangat layak \\
\hline 5 & $\begin{array}{l}\text { Kompatibilitas (dapat } \\
\text { dipasang/diinstalasi } \\
\text { diberbagai software dan } \\
\text { hardware yang ada) }\end{array}$ & 3,00 & 4,00 & 75,00 & Cukup Layak \\
\hline 6 & $\begin{array}{l}\text { Pemaketan program yang } \\
\text { terpadu dan mudah untuk } \\
\text { dieksekusi }\end{array}$ & 4,00 & 4,00 & 100,00 & Sangat Layak \\
\hline 7 & Petunjuk pemakaian jelas & 4,00 & 4,00 & 100,00 & Sangat Layak \\
\hline 8 & $\begin{array}{l}\text { Reuseable (dapat } \\
\text { dimanfaatkan kembali untuk } \\
\text { pengembangan media } \\
\text { selanjutnya) }\end{array}$ & 4,00 & 4,00 & 100,00 & Sangat Layak \\
\hline 9 & $\begin{array}{l}\text { Kreatif dalam ide berikut } \\
\text { penuangan gagasan }\end{array}$ & 4,00 & 4,00 & 100,00 & Sangat Layak \\
\hline 10 & Menarik dan memikat & 4,00 & 4,00 & 100,00 & Sangat Layak \\
\hline 11 & $\begin{array}{l}\text { Audio (soundeffect, backsound, } \\
\text { narasi, musik) }\end{array}$ & 3,00 & 4,00 & 75,00 & Cukup Layak \\
\hline 12 & $\begin{array}{l}\text { Visual (layout design, } \\
\text { typography, warna, } \\
\text { resolusi/detail, kontras) }\end{array}$ & 4,00 & 4,00 & 100,00 & Sangat Layak \\
\hline 13 & $\begin{array}{l}\text { Media bergerak (animasi, } \\
\text { movie) }\end{array}$ & 4,00 & 4,00 & 100,00 & Sangat Layak \\
\hline \multirow[t]{2}{*}{14} & $\begin{array}{l}\text { Layout Interactive (tombol } \\
\text { navigasi) }\end{array}$ & 4,00 & 4,00 & 100,00 & Sangat Layak \\
\hline & Jumlah & 53,00 & 56,00 & 94,64 & Sangat Layak \\
\hline
\end{tabular}


Berdasarkan hasil perhitungan yang telah tercantum pada Tabel 1. diperoleh hasil validasi produk oleh ahli media dengan nilai 94,64\%. Nilai tersebut menunjukkan bahwa produk pengembangan multimedia pembelajaran materi sistem respirasi manusia dari aspek media termasuk dalam kriteria sangat layak. Multimedia akan direvisi berdasarkan saran dan masukan dari validator media.

Tabel 2. Rekapitulasi Data Hasil Validasi oleh Ahli Materi

\begin{tabular}{|c|c|c|c|c|c|}
\hline \multirow{2}{*}{ No. } & \multirow{2}{*}{ Aspek yang Dinilai } & \multicolumn{2}{|l|}{ Skor } & \multirow{2}{*}{ Presentase } & \multirow{2}{*}{ Kriteria } \\
\hline & & $\sum \mathrm{X}$ & $\sum X i$ & & \\
\hline 1. & Kebenaran konsep & 4,00 & 4,00 & $100,00 \%$ & Sangat valid \\
\hline 2. & $\begin{array}{l}\text { Cakupan dan kedalaman } \\
\text { konsep }\end{array}$ & 4,00 & 4,00 & $100,00 \%$ & Sangat valid \\
\hline 3. & Sistematika penyajian materi & 3,00 & 4,00 & $75,00 \%$ & Cukup valid \\
\hline 4. & $\begin{array}{l}\text { Kemudahan konsep untuk } \\
\text { dipahami }\end{array}$ & 4,00 & 4,00 & $100,00 \%$ & Sangat valid \\
\hline 5. & Kesesuaian alat evaluasi & 4,00 & 4,00 & $100,00 \%$ & Sangat valid \\
\hline 6. & $\begin{array}{l}\text { Umpan balik terhadap hasil } \\
\text { evaluasi }\end{array}$ & 4,00 & 4,00 & $100,00 \%$ & Sangat valid \\
\hline \multicolumn{2}{|c|}{ Jumlah } & 23 & 24 & $95,83 \%$ & Sangat valid \\
\hline
\end{tabular}

Berdasarkan hasil perhitungan yang telah tercantum pada Tabel 2 diperoleh hasil validasi produk oleh ahli materi dengan nilai 95,83\%. Nilai tersebut menunjukkan bahwa produk pengembangan multimedia pembelajaran dalam aspek materi termasuk dalam kriteria sangat layak. Multimedia akan direvisi berdasarkan saran dan masukan dari validator materi.

Tabel 3. Rekapitulasi Data Hasil Validasi oleh Praktisi Lapangan

\begin{tabular}{|c|c|c|c|c|c|}
\hline \multirow{2}{*}{ No. } & \multirow{2}{*}{ Aspek yang Dinilai } & \multicolumn{2}{|l|}{ Skor } & \multirow{2}{*}{ Presentase } & \multirow{2}{*}{ Kriteria } \\
\hline & & $\sum \mathrm{X}$ & $\sum \mathrm{Xi}$ & & \\
\hline 1. & $\begin{array}{l}\text { Kesesuaian materi dengan } \\
\text { KI, KD dan tujuan } \\
\text { pembelajaran }\end{array}$ & 4,00 & 4,00 & $100,00 \%$ & Sangat valid \\
\hline 2. & $\begin{array}{l}\text { Kesesuaian multimedia } \\
\text { pembelajaran dengan } \\
\text { strategi pembelajaan }\end{array}$ & 4,00 & 4,00 & $100,00 \%$ & Sangat valid \\
\hline 3. & $\begin{array}{l}\text { Keseuaian multimedia } \\
\text { pembelajaran dengan } \\
\text { perkembangan intelektual } \\
\text { peserta didik }\end{array}$ & 3,00 & 4,00 & $75,00 \%$ & Cukup valid \\
\hline 4. & Kesesusaian alat evaluasi & 4,00 & 4,00 & $100,00 \%$ & Sangat valid \\
\hline 5. & $\begin{array}{l}\text { Umpan balik terhadap hasil } \\
\text { evaluasi }\end{array}$ & 4,00 & 4,00 & $100,00 \%$ & \\
\hline \multicolumn{2}{|c|}{ Jumlah } & 19,00 & 20,00 & $95,00 \%$ & Sangat valid \\
\hline
\end{tabular}

Berdasarkan hasil perhitungan yang telah tercantum pada Tabel 3 diperoleh hasil validasi produk oleh praktisi lapangan dengan nilai 95,00\%. Nilai tersebut menunjukkan bahwa produk pengembangan multimedia pembelajaran termasuk dalam kriteria sangat layak. Multimedia akan direvisi berdasarkan saran dan masukan dari praktisi lapangan. 
Hasil validasi menunjukkan bahwa multimedia pembelajaran yang dikembangkan memiliki kriteria sangat layak baik dari segi materi maupun dari segi media. Multimedia pembelajaran yang dikembangkan dikemas dalam satu folder dengan 3 loader. Dilakukan pemisahan loader bertujuan agar pengoperasian multimedia pembelajaran berjalan lancar. Multimedia pembelajaran yang dikembangkan banyak memuat animasi dan video yang menyebabkan ukuran loader sangat besar sehingga pengoperasian media menjadi sangat berat. Dengan dilakukan pemisahan aplikasi menjadi 3 loader, aplikasi utama yang semula ukurannya besar menjadi lebih kecil. Nugroho (2008) menjelaskan bahwa, loader yang memiliki ukuran besar akan berjalan lambat pada saat dioperasikan atau bahkan tidak dapat dioperasikan sama sekali

Multimedia pembelajaran yang dikembangkan dilengkapi aplikasi flash player yang memungkinkan multimedia pembelajaran untuk dapat dioperasikan pada komputer yang belum terinstal adobe flash. Multimedia pembelajaran dikembangkan menggunakan software adobe flash professional CS. 6 yang merupakan salah satu software dari Adobe untuk desain animasi 2 dimensi. Multimedia pembelajaran yang dikembangkan memiliki format loader berjenis *exe dan *swf dimana kedua jenis format tersebut dapat dibuka pada komputer yang sudah terinstal flash player. Flash player merupakan aplikasi bawaan yang otomatis akan terinstal pada saat menginstal adobe flash tetapi dapat diinstal secara manual tanpa harus menginstal adobe flash terlebih dahulu (Enterpize, 2007).

Video yang dimuat dalam multimedia pembelajaran sebagian besar merupakan video yang diunduh dari internet dengan narasi dalam bahasa asing. Sebelum video diintegrasikan kedalam multimedia pembelajaran, narasi yang semula dalam bahasa asing diganti menjadi bahasa Indonesia dengan cara didobbing ulang. Hal ini bertujuan agar konsep yang disampaikan oleh video tersebut lebih mudah untuk dipahami oleh peserta didik.

Multimedia pembelajaran sistem respirasi manusia ini memiliki tiga menu utama yaitu, tujuan pembelajaran, materi dan kuis. Menu materi terdiri dari pokok bahasan struktur dan fungsi alat pernapasan manusia, mekanisme pernapasan manusia (inhalasi, ekshalasi, pernapasan dada dan perut serta pertukaran gas), kapasitas dan volume paru-paru manusia, frekuensi pernapasan manusia, gangguan serta kelainan pada alat pernapasan manusia. Konsep materi yang dimuat dalam multimedia pembelajaran dikelompokkan kedalam frame yang berbeda-beda. Pada setiap frame diberi nomer halaman sebagai urutan dalam mempajari konsep sehingga sistematis.

\subsection{Uji Coba Lapangan}

Multimedia yang telah direvisi selanjutnya akan diuji cobakan ke kelas XI IPA MAN Malang II Batu dalam pembelajaran selama 7 x pertemuan dengan alokasi waktu 14 x 45 menit untuk mengetahui kepraktisan, keefektifan, dan peningkatan hasil belajar kognitif. 


\subsubsection{Kepraktisan Multimedia}

Tabel 4. Rekapitulasi Data Hasil Uji kepraktisan

\begin{tabular}{llllll}
\hline \multirow{2}{*}{ No. } & \multirow{2}{*}{ Aspek yang Dinilai } & \multicolumn{2}{l}{ Skor } & Presenta & Kriteria \\
\cline { 3 - 4 } & $\sum \mathrm{P}$ & $\sum \mathrm{Pi}$ & se & \\
\hline 1. & Kemenarikan & 26 & 28 & $92,86 \%$ & Sangat Praktis \\
2. & $\begin{array}{l}\text { Kemudahan } \\
\text { pengoperasian }\end{array}$ & 28 & 28 & $100 \%$ & Sangat Praktis \\
\multirow{2}{*}{3.} & $\begin{array}{l}\text { Kemudahan materi untuk } \\
\text { dipahami }\end{array}$ & 26 & 28 & $92,86 \%$ & Sangat Praktis \\
\hline Jumlah & & 80 & 84 & $95,24 \%$ & Sangat Praktis \\
\hline
\end{tabular}

Berdasarkan data pada Tabel 4 diperoleh hasil uji kepraktisan dengan nilai 95,24\%. Nilai tersebut menunjukkan bahwa produk pengembangan multimedia pembelajaran termasuk dalam kriteria sangat praktis. Multimedia akan diperbaiki berdasarkan saran dan masukan dari siswa sekaligus mennjadi produk akhir dari penelitian dan pengembangan ini.

Hasil uji kepraktisan dengan nilai 95,24\% menunjukkan bahwa produk pengembangan multimedia pembelajaran berbasis flash termasuk dalam kriteria sangat praktis. Multimedia pembelajaran yang dikembangkan menarik dan diminati oleh peserta didik. Multimedia pembelajaran yang dikembangkan dirancang dengan tampilan yang menarik seperti pemilihan tema pada background, backsound jenis instrumental yang bervariasi, serta beragam jenis animasi dan video yang bersifat unik dan kontekstual. Nugroho (2008) menyatakan bahwa adobe flash memberikan keleluasaan kepada pengembang multimedia pembelajaran dalam berkreasi membuat tampilan yang dikehendaki seperti tema background, penyisipan backsound, animasi logo dan lain sebagainya sehingga dapat menciptakan media yang menarik dan diminati oleh peserta didik.

Konsep materi yang termuat dalam multimedia pembelajaran mudah untuk dipelajari karena lebih banyak disampaikan melalui audio visual dengan narasi dalam bahasa Indonesia. Selain itu pada setiap gambar, animasi, video dan grafik diberi keterangan penjelas untuk memudahkan penyampaian pesan yang terkandung didalamnya.

\subsubsection{Keefektifan Multimedia}

Rekapitulasi data nilai ulangan harian materi sistem respirasi manusia menunjukkan bahwa tingkat ketuntasan belajar klasikal peserta didik yang menggunakan multimedia pembelajaran pada saat proses pembelajaran materi sistem respirasi manusia adalah 91,67 $\%$. Nilai tersebut menunjukkan bahwa multimedia yang telah dikembangkan memiliki kriteria efektif.

Ketuntasan belajar klasikal yang dicapai setelah siswa dibelajarkan menggunakan multimedia berbasis flash adalah $>85 \%$ sehingga multimedia pembelajaran yang dikembangkan memiliki kriteria efektif. Flash memberikan kemudahan kepada pengembang untuk mengintegrasikan unsur gambar, animasi, beragam video unik dan kontekstual, serta grafik yang memungkinkan penyajian ilustrasi suatu konsep lebih banyak serta memberikan keseragaman persepsi kepada peserta didik tentang peristiwa-peristiwa yang tidak dapat diamati. Menurut teori pengalaman belajar Dale (1946) bahwa proses pembelajaran yang 
menggunakan ilustrasi untuk menggambarkan suatu konsep abstrak akan memberikan pemahaman serta ingatan lebih terhadap peserta didik daripada membaca buku teks atau mendengarkan penjelasan guru.

\subsubsection{Peningkatan Hasil Beajar Kognitif}

Ketuntasan belajar klasikal setelah siswa dibelajarkan menggunakan multimedia adalah 91,67\% sedangkan ketuntasan belajar klasikal siswa pada tahun 2014 yang tidak menggunakan multimedia pembelajaran adalah $72,2 \%$. Sehingga multimedia yang dikembangkan mampu meningkatkan hasil belajar kognitif siswa.

Multimedia pembelajaran yang dikembangkan mampu meningkatkan hasil belajar kognitif peserta didik materi sistem respirasi manusia. Peserta didik kelas XI IPA MAN Malang II Batu tahun 2014 yang tidak menggunakan multimedia pembelajaran dalam proses pembelajaran materi sistem respirasi manusia, hanya menggunakan media berupa model dan torso yang kurang diminati oleh peserta didik. Selain kurang diminati oleh peserta didik, media berupa model atau alat peraga lemah dalam menjelaskan sebuah konsep yang berupa alur atau peristiwa yang sistematis. Penggunaan media yang tepat dalam proses pembelajaran, memudahkan peserta didik untuk mencapai tujuan belajar (Arsyad, 2007).

\section{Simpulan}

Multimedia pembelajaran berbasis flash memiliki kriteria sangat layak, sangat praktis dan efektif sehingga mampu meningkatkan hasil belajat kognitif siswa. Saran untuk penelitian selanjutnya yaitu multimedia pembelajaran yang dikembangkan hendaknya diujicobakan pada lingkungan yang lebih luas.

\section{Daftar Rujukan}

Arsyad, A. (2007). Media Pembelajaran. Jakarta: PT Raja Grafindo Persada.

Bagus, A. S. (2012). Penggunaan Multimedia Macromedia Flash untuk Meningkatkan Motivasi, Keaktifan dan Hasil Belajar Ekonomi dengan Strategi Pembelajaran Kontekstual. Skripsi tidak diterbitkan. Malang: Jurusan Pendidikan Ekonomi FE UM.

Dale, E. (1946). Audio-Visual Methods in Teaching. US: Dryden Press.

Enterprise, Jubilee. (2007). Flash CS3. Jakarta: PT Elex Media Komputindo.

Nugroho, Bunafit. (2008). Aneka Kreasi Animasi dengan Adobe Flash CS3. Jakarta: PT Elex Media Komputindo.

Sayekti, P., Irwanto, R., Istiar, M. \& Priyatmono, D. (2011). Pelatihan Perancangan Media Pembelajaran Berbasis Multimedia Interaktif bagi Guru SMA dalam Upaya Pemanfaatan Teknologi Komputer untuk Peningkatan Kualitas Pembelajaran. Malang: PPs UM.

Suherman, Y. (2009). Pengembangan Media Pembelajaran Bagi ABK. Makalah disajikan dalam Diklat Profesi Guru PLB Wilayah X Jawa Barat, Lembang Bandung.

Thiagarajan, S., Semmel, D. S., dan Semmel, M. I. (1974). Instructional Development for Training Teachers of Exceptional Children: A sourcebook. USA: Indiana University.

Zalikha, N. (2008). Pengaruh Penggunaan Multimedia Interaktif Dalam Model Pembelajaran Aktif (Active Learning) Tipe True Or False Terhadap Motivasi, Keaktifan dan Hasil Belajar Biologi Siswa. Surakarta: Skripsi tidak diterbitkan. Fakultas Keguruan dan Ilmu Pendidikan. Universitas Sebelas Maret. 